\title{
南極磁気図の作成
}

\author{
春山 仁*

\section{Compilation of Magnetic Charts for Antarctic Region}

\author{
Hitoshi HaRuYama
}

\begin{abstract}
"Magnetic Maps 1975 of the Antarctic" has been compiled by the Geographical Survey Institute (GSI). Most of its data have been sent to GSI by countries joining to the Scientific Committee on Antarctic Research (SCAR) at its request through SCAR to be submitted to the spherical harmonic analysis.

Distribution of the earth's magnetic field and its annual change are represented in seven maps corresponding to each component by the illustration of isomagnetic and isoporic lines respectively. Residual total intensity at the observation points is shown on the eighth map.

Location of the south magnetic pole is obtained. It has been moving on the Continent toward north or northwest direction and is now located at a point off the coast of Adelie Land. It appears that the dipole moment of the earth's magnetic field is still decreasing at an approximately constant rate.
\end{abstract}

\section{I はじめに}

国土地理院では, 南極研究科学委員会 (SCRA) の依頼によって，昭和51年 4 月から南極磁気図の 作成を進めてきて拉り, 昭和53年 8 月には完成の 見込である。

SCAR は，南極観測を実施しているアルゼン チン, オーストラリア, ベルギー, チリ, フラン ス, 日本, ニュージーランド, ノルウェー, 南ア フリカ, イギリス，アメリカ及びソ連の12国で構 成される国際的な学術団体の 1 つであり, 南極の 科学的調查,観測に関する国際協力を行っている。 南極磁気図はこれまでにもソ連, アメリカ等で 作成されたことがあるが1,2)，今回の SCAR の 試みは，国際協力によって各国のデータを集大成 しようとするものであり，国土地理院としても，

\footnotetext{
* 国土地理院 Geographical Survey Institute
}

国際協力の一環として要請に応ずることとなった のである。

\section{II 地磁気について}

中低緯度地域において磁針がほぼ南北を指すこ とはかなり昔から知られて打り，羅針盤による船 舶の進路決定等に利用されてきているが，このこ とは地球が磁気を持っているために生ずる現象で あり，地球の持つ磁気のことを地磁気と呼んでい る。地磁気については，その大部分は地球流体核 内部を流れる電流によって生じ, 電流を定常的に 維持するために流体核内に発電機と同し原理のメ カニズムが成立しているとする，いわゆるダイナ モ理論が，現在では一般的に認められている。

地磁気の分布は，地球の中心部に地軸とほぼ平 行に1本の棒磁石があると考えた場合の分布と比 較的似ているが，その他に世界各地に地域的な異 常があり，さらにそれより狭い範囲の局地的な異 
常も重なり合って，かなり複雑である。このよう に，場所によって異なる地磁気の分布を地図上に 表現したものが磁気図である。

地磁気はまた，時間とともに変化する。その代 表的なものは 1 日を周期とする日変化であり，あ るいは地磁気の值が突然大きく擾乱されるいわ ゆる磁気嵐である。これらの変化の原因は, 電離 層ないしそれより外側の空間での太陽・地球間の 相互作用であるとされている。その他にも，数 10 年程度以上の長い期間にわたって徐々に変ってゅ く部分があり，永年変化と呼ばれている。このよ うな地磁気の性質から, 磁気測量の結果をまとめ て磁気図を作成する際には, 適当な時点 (エポッ ク）を定めて，観測值をエポックにおける值に引 直すことが必要である。この引直しは, 国土地理 院では年度化成と呼ばれている。

永年変化を示すものとしては，年変化量があ る。年度化成を行うためには年変化量に関する知 識が必要なので，磁気図作成に際しては，同時に 年変化量分布図も作成されることが多い。

\section{III 磁気ポテンシャル}

地磁気は, 磁気ポテンシャルを考えることによ って，その取扱いが比較的簡単になる。磁気物質 のない空間においては，磁気ポテンシャルVが定 義でき，地心を極とする極座標を $(\mathrm{r}, \theta, \lambda)$ とす ると, Vは微分方程式

$$
\begin{gathered}
\frac{1}{\mathrm{r}^{2}} \frac{\partial}{\partial \mathrm{r}}\left(\mathrm{r}^{2} \frac{\partial \mathrm{V}}{\partial \mathrm{r}}\right)+\frac{1}{\mathrm{r}^{2} \sin \theta} \frac{\partial}{\partial \theta}\left(\sin \theta \frac{\partial \mathrm{V}}{\partial \theta}\right) \\
+\frac{1}{\mathrm{r}^{2} \sin ^{2} \theta} \frac{\partial^{2} \mathrm{~V}}{\partial \lambda^{2}}=0
\end{gathered}
$$

を満足する。この方程式の解には球関数が用いら れるが，磁気ポテンシャルの場合には，ルジャン ドル陪関数 Pn, m $(\theta)$ の代りにシュミット球関 数 $\mathrm{P}_{\mathrm{n}}{ }^{\mathrm{m}}(\theta)$ が用いられることが多い3)。この $2 つ$ の関数は

$$
\begin{aligned}
& \mathrm{P}_{\mathrm{n}}{ }^{\mathrm{m}}(\theta)=\mathrm{Pn}, \mathrm{m}(\theta) \\
& \left.\mathrm{P}_{\mathrm{n}} \mathrm{m}(\theta)=\sqrt{2 \frac{(\mathrm{n}-\mathrm{m}) !}{(\mathrm{n}+\mathrm{m}) !}} \mathrm{Pn}, \mathrm{m}(\theta) \mathrm{m}>0\right\}
\end{aligned}
$$
といら関係で結ばれており, シュミット球関数の 具体形は

$$
\mathrm{P}_{1}{ }^{0}(\theta)=\cos \theta
$$

$\mathrm{P}_{1}{ }^{1}(\theta)=\sin \theta$

$\mathrm{P}_{2}{ }^{0}(\theta)=\frac{1}{2}\left(3 \cos ^{2} \theta-1\right)$

$\mathrm{P}_{2}{ }^{1}(\theta)=\sqrt{3} \sin \theta \cos \theta$

$\mathrm{P}_{2}^{2}(\theta)=\frac{\sqrt{3}}{2} \sin ^{2} \theta$

となる。

地磁気は, 地球内部が原因となる部分と, 地球 外部に起因する部分との和であるが, 後者は前者 にくらべて小さいため, 球関数分析に際しては, 後者を無視することが慣例となっている。その場 合, 微分方程式の解は

$$
\begin{aligned}
\mathrm{V}= & \mathrm{a}_{\mathrm{o}} \sum_{\mathrm{n}=1}^{\infty} \sum_{\mathrm{m}=0}^{\mathrm{n}}\left(\frac{\mathrm{a}_{\mathrm{o}}}{\mathrm{r}}\right)^{\mathrm{n}+1} \\
& \left\{\mathrm{~g}_{\mathrm{n}}{ }^{\mathrm{m}} \cos \mathrm{m} \lambda+\mathrm{h}_{\mathrm{n}}{ }^{\mathrm{m}} \sin \mathrm{m} \lambda\right\} \mathrm{P}_{\mathrm{n}} \mathrm{m}(\theta)
\end{aligned}
$$

となる。ここで $\mathrm{g}_{\mathbf{n}}{ }^{\mathrm{m}}, \mathrm{h}_{\mathbf{n}}{ }^{\mathrm{m}}$ はガウス係数と呼ばれ る定数であり，a１はガウス係数を決定する際に 基準としてとられる球面の半径である。

地磁気の永年変化は, 磁気ポテンシャルの変化 として考えることができる。このとき変化するも のはガウス係数であり, その年変化量が通常 $\dot{\mathrm{g}}_{\mathrm{n}}{ }^{\mathrm{m}}$, $\dot{\mathrm{h}}_{\mathrm{n}} \mathrm{m}$ 之書かれる。これらの值を前式右辺のガウス 係数の代りに用いれば，ポテンシャルの年変化量 ப்が得られる。

\section{IV 国際標準地球磁場}

これまで多くの研究者によって, 種々のエポッ クに抢けるガウス係数が求められているが, 議論 の基礎となるこれらの数值は共通のものを使用す ることが望ましいといら事情があって，国際標準 地球磁場 (IGRF) が設けられた。現在までに1965 年及び1975年の 2 つのエポックにおける数值が公

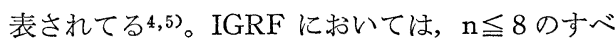
ての係数及びその年変化量が定められて打り，そ の一部を表 1 に示す。

\section{$\mathrm{V}$ 地磁気の成分}

地磁気は方向と大きさとを持つ, いわゆるべク トル量であり, 互に独立な 3 つの成分であらわさ れる。磁気ポテンシャルの定義されている空間内 の 1 点に扔いて, 地磁気の直交 3 成分は

$$
\mathrm{X}^{\prime}=\frac{1}{\mathrm{r}} \frac{\partial \mathrm{V}}{\partial \theta}
$$


表 1 IGRF 1975 の係数

\begin{tabular}{l|r|r|r|r|r}
\hline \hline $\mathrm{n}$ & $\mathrm{m}$ & $\mathrm{g}_{\mathrm{n}} \mathrm{m}(\mathrm{nT})$ & $\mathrm{h}_{\mathrm{n}} \mathrm{m}(\mathrm{nT})$ & $\begin{array}{c}\dot{\mathrm{g}}_{\mathrm{n}} \mathrm{m} \\
(\mathrm{nT} / \mathrm{y})\end{array}$ & $\begin{array}{c}\dot{\mathrm{h}}_{\mathrm{n}} \mathrm{m} \\
(\mathrm{nT} / \mathrm{y})\end{array}$ \\
\hline 1 & 0 & $-30,186$ & & 25.6 & \\
& 1 & $-2,036$ & 5,735 & 10.0 & -10.2 \\
2 & 0 & $-1,898$ & & -24.9 & \\
& 1 & 2,997 & $-2,124$ & 0.7 & -3.0 \\
& 2 & 1,551 & -37 & 4.3 & -18.9 \\
& 0 & 1,299 & & -3.8 & \\
& 1 & $-2,144$ & -361 & -10.4 & 6.9 \\
& 2 & 1,296 & 249 & -4.1 & 2.5 \\
& 3 & 805 & -253 & -4.2 & -5.0 \\
& 0 & 951 & & -0.2 & \\
& 1 & 807 & 148 & -2.0 & 5.0 \\
& 2 & 462 & -264 & -3.9 & 0.8 \\
& 3 & -393 & 37 & -2.1 & 1.7 \\
& 4 & 235 & -307 & -3.1 & -1.0
\end{tabular}

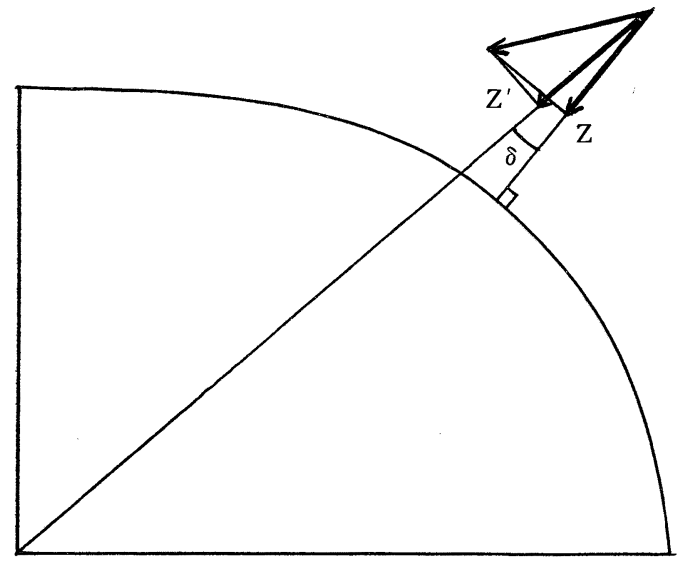

図 1

$$
\begin{aligned}
& \mathrm{Y}^{\prime}=\frac{-1}{\mathrm{r} \sin \theta} \frac{\partial \mathrm{V}}{\partial \lambda} \\
& \mathrm{Z}^{\prime}=\frac{\partial \mathrm{V}}{\partial \mathrm{r}}
\end{aligned}
$$

であらわされる。ここで $Z^{\prime}$ は，地心に向ら方向 の成分であり, 通常用いられている棈円体の法線 方向の成分とは，わずかではあるが異なっている (図 1)。この 2 つの方向のなす角を $\delta$ とすれば， 通常の座標系での成分值は次式によって計算でき る。

$$
\mathrm{X}=\mathrm{X}^{\prime} \cos \delta+\mathrm{Z}^{\prime} \sin \delta
$$

$$
\begin{aligned}
& \mathrm{Y}=\mathrm{Y}^{\prime} \\
& \mathrm{Z}=\mathrm{Z}^{\prime} \cos \delta-\mathrm{X}^{\prime} \sin \delta
\end{aligned}
$$

ここで $\mathrm{X}, \mathrm{Y}, \mathrm{Z}$ はそれぞれ北，東，下向きの成 分である。

準拠楕円体の赤道半径を $\mathrm{a}$, 極半径を $\mathrm{b}$ とし, この点の緯度, 経度をそれぞれ $\mathrm{B} ， \mathrm{~L}$ とすれば, $\delta$ は

$$
\sin \delta=\frac{\cos \mathrm{B} \sin \mathrm{B}}{\mathrm{r} \sqrt{\mathrm{a}^{2} \cos ^{2} \mathrm{~B}+\mathrm{b}^{2} \sin ^{2} \mathrm{~B}}}
$$

によって計算される。

地磁気ベクトルの成分としては, この他に, 水 平成分 $\mathrm{H}$ ， ベクトルの大きさ $\mathrm{F}$ (全磁力)，方位角 $\mathrm{D}$ (偏角), 水平からの傾き I (伏角) が時により 使い分けられて抢り，これらの成分はいずれも前 記 3 成分から求方られ。図 2 は, これらの成分 の関係を示したものである。

\section{VI データ収集}

磁気図作成のために必要な観測所の月（または 年）平均值及び野外測量の観測データについて は，SCAR を通じ各国の国内南極委員会に対し て提供を依頼した。その結果, オーストラリア, フランス, 日本, ニュージーランド, 南アフリ カ，イギリス，アメリカ及びソ連の 8 カ国からデ ータが提供された。

観測所データについては, その他に, 京都大学 内にある世界データセンターで蓄積されている資 料及び出版された資料も参照した。当初，南緯 30 度以南の27観測所のデータを収集したが，このう ち 6 籄所は観測期間が 3 年未満であるため, 年変 化量の解析に当っては除外した。その他に, 後に 述べる理由により南緯30度以北にある11観測所を 追加し, 最終的に32箇所のデータを使用した。こ れらの観測所を表 2 に示す。

野外デー夕については, 収集されたもののう ち，南緯40度以南の海上又は陸上で，1957年以降 に観測されたものを採用した。観測された成分は 点により種々の組合せがあるが，独立な 3 成分の 観測がある場合にはすべて（X, Y, Z ）成分に 変換して，以後の処理を行った。その他の場合に は，Fまたは $\mathrm{F}$ の観測されているむのに限って採 用した。これらの選択を行い, さらに後述するよ 


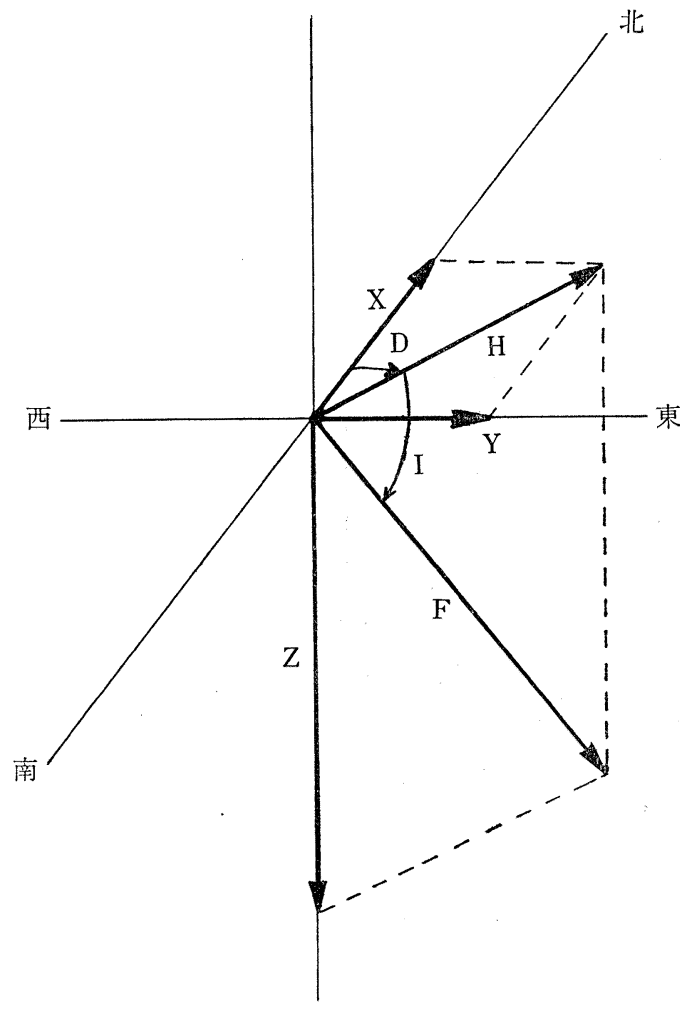

仳 2

うに不適切なデータを排除した結果, 最終的に使 用されたデータ数は，3成分の観測のある点が観 測所を含め 849 点, $\mathrm{F}$ 成分のみ 8,022 点, Z成分の み 712 点, 合計 9,583 点である。

\section{VII 年度化成}

地磁気の時間的変化のうち, 短周期変化部分に ついては，南極地域に扔ける観測所の分布が十分 でないこと及び観測所の連続記録資料が入手され なかったことから無視し，永年変化のみを考慮し て，1975.0年に化成した。

永年変化に対する補正の手順は, 次のとおりで ある。

観測所における各成分の月または年平均值が, 時間Tの 3 次式であらわされると仮定して

$$
\begin{aligned}
& X=X_{1} T^{3}+X_{2} T^{2}+X_{3} T+X_{4} K_{1}+X_{5} K_{2} \\
& Y=Y_{1} T^{3}+Y_{2} T^{2}+Y_{3} T+Y_{4} K_{1}+Y_{5} K_{2} \\
& Z=Z_{1} T^{3}+Z_{2} T^{2}+Z_{3} T+Z_{4} K_{1}+Z_{5} K_{2}
\end{aligned}
$$

とおき，最小二乗法により，観測所ごとに係数 $\mathrm{X}_{1}, \mathrm{X}_{2}, \cdots, Z_{5}$ を決定した。このとき, Tの単 位は年とする。ここで, 右辺の第 4 項及び第 5 項 はいずれも定数項で, 通常は $\mathrm{K}_{1}=1, \mathrm{~K}_{2}=0$ であ るが, 観測点が移転した場合には, 移転後は $\mathrm{K}_{1}=$ $0, \mathrm{~K}_{2}=1$ とする。すなわち，これら 2 つの観測 点はあまり離れていないので変化の傾向は同じで あると仮定して，移転前後のデータを統一して报 うことができるようにしたものである。求められ た係数の一部を, 表 3 に示す。

この式により，1957年から1975年までの各年初 に打ける值を算出し，それらの差をとることによ って, 各観測所について 1 年ごとの年変化量が求 められる。表 2 加らわかるように，全期間にわた るデータの得られていない観測所が多いが，この 場合には，データの欠けている期間のうち最初の 1 年については 3 次曲線を延長して年変化量を算 出するが，それ以後については計算しないことと した。

観測所ごとの 3 成分の年変化量が計算される と, 最小二乗法により $\dot{\mathrm{g}}_{\mathrm{n}}{ }^{\mathrm{m}}, \dot{\mathrm{h}}_{\mathrm{n}}{ }^{\mathrm{m}}$ が得られる。 れらの值が1957年から1974年までの各年について 計算された。ただし，観測方程式の数を考虑し て, $\mathrm{n} \leqq 4$ の合計 24 個について求められている。 主要項の数值の変化の椂子を表 4 亿示す。

年変化量図を作成するために必要な1975.0年の 年変化量のみは, この時点にお注る 3 次曲線の接 線の勾配から求められた。 $\dot{\mathrm{g}}_{\mathrm{n}} \mathrm{m}, \dot{\mathrm{h}}_{\mathrm{n}}{ }^{\mathrm{m}}$ 在求めるた めのその後の処理は, 他の場合と同様である。

$\dot{\mathrm{g}}_{\mathrm{n}}{ }^{\mathrm{m}}, \dot{\mathrm{h}}_{\mathrm{n}} \mathrm{m}$ が与えられれば $\dot{\mathrm{X}}, \dot{\mathrm{Y}}, \dot{\mathrm{Z}}$ は計算でき る。 $\dot{\mathrm{F}}$ の計算式は

$$
\dot{\mathrm{F}}=(\mathrm{X} \dot{\mathrm{X}}+\mathrm{Y} \dot{\mathrm{Y}}+\mathrm{Z} \dot{\mathrm{Z}}) / \mathrm{F}
$$

であるが，この段階では X, Y, Z, F が末決定で ある。そこでX等には，IGRF 1975によって計算 された值を用いた。

これら 4 種の年変化量が緯度 2 度, 経度 4 度ご との格子点において計算され, 各観測地点におけ る年変化量は, 格子点值から 2 次元の内雨によっ て求められた。内挿方式を用いたのは, 計算量を 節約するためである。

観測時点からエポックまで年変化量を積算し， これを観測值に加えれば，エポックに化成した值 
春山 仁

表 2 年度化成に使用した地磁気観測所

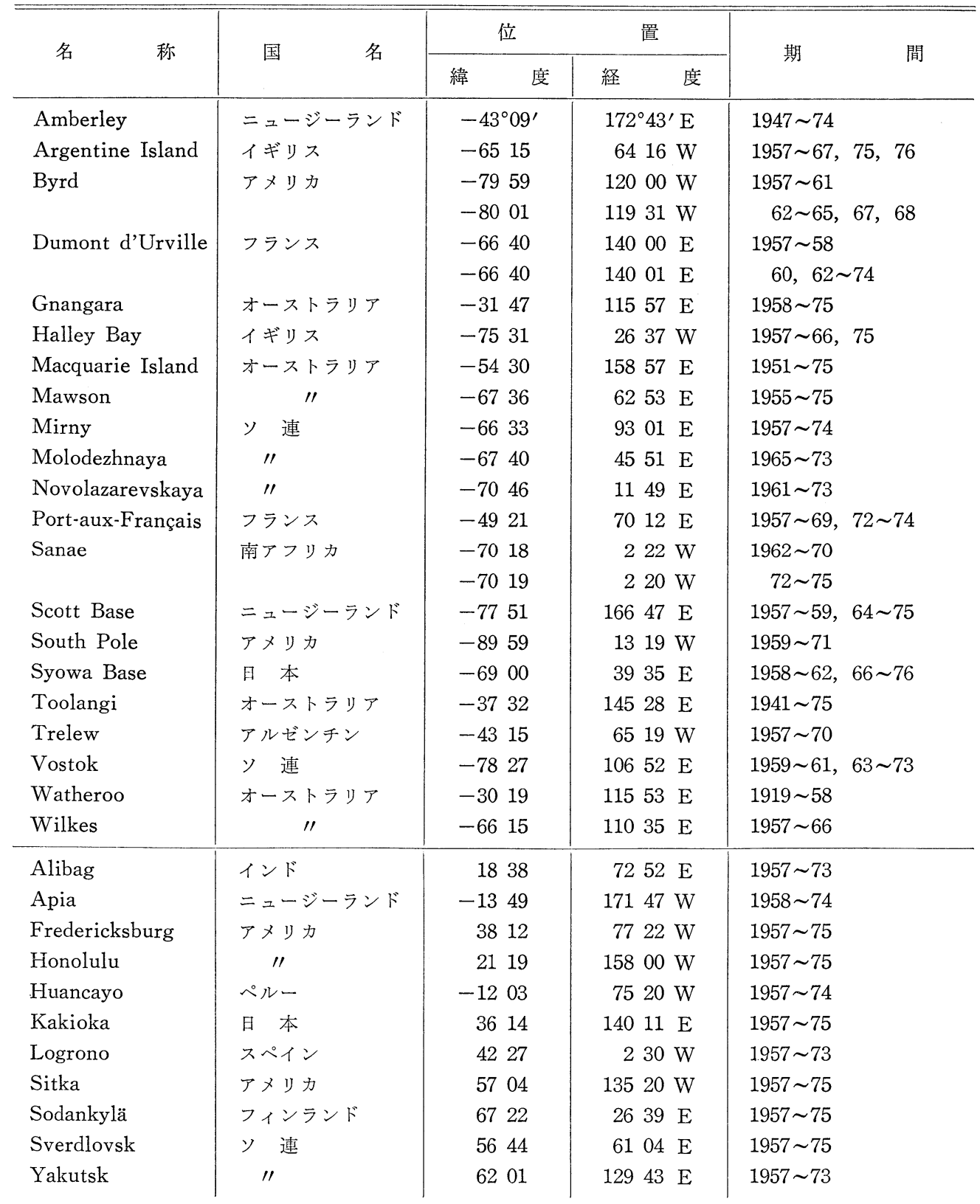

が得られる。

\section{VIII データの吟味}

年度化成の終ったデータについては，まず IGRF 1975による計算值との差を求めた。主な目
的は, 収集された原データからパンチカードを作 成する際の㗐りを発見することであり, これらの 誤りは訂正された。

その他に一連の海上測定において，原データの 経度の符号が混乱しているグループが発見され 
表 $3 \quad Z$ の永年変化式の係数

\begin{tabular}{|c|c|c|c|c|c|}
\hline 観 測 所 & $Z_{1}$ & $Z_{2}$ & $\mathrm{Z}_{3}$ & $\mathrm{Z}_{4}$ & $Z_{5}$ \\
\hline Amberley & -.03 & 1.35 & 10.4 & $-55,189.1$ & - \\
\hline Argentine Island & .01 & -1.81 & 151.0 & $-38,057.0$ & - \\
\hline Byrd & -.46 & 19.31 & -148.0 & $-58,542.1$ & $-58,388.9$ \\
\hline Dumont d'Urville & -.91 & 45.35 & -662.6 & $-68,310.0$ & $-68,119.0$ \\
\hline Gnangara & -.09 & 4.87 & -81.5 & $-53,069.5$ & - \\
\hline Halley Bay & .84 & -41.89 & 715.8 & $-47,259.6$ & - \\
\hline Macquarie Island & -.05 & 2.33 & $-\quad 1.9$ & -64.572 .5 & - \\
\hline Mawson & -.12 & 7.72 & -53.9 & $-48,945.3$ & - \\
\hline Mirny & -.09 & 5.61 & -35.1 & -60487.8 & - \\
\hline Molodezhnaya & -.52 & 40.80 & -896.6 & $-37,132.5$ & - \\
\hline Novolazarevskaya & .45 & -25.46 & 584.3 & $-43,893.7$ & - \\
\hline Port Français & -.10 & 10.27 & -251.9 & $-42,568.7$ & - \\
\hline Sanae & -.25 & 14.49 & -147.9 & $-38,411.3$ & $-38,476.4$ \\
\hline Scott Base & .04 & -2.48 & 133.3 & $-70,389.5$ & - \\
\hline South Pole & -.57 & 26.75 & -287.3 & $-56,331.9$ & - \\
\hline Syowa Base & -.11 & 7.07 & $-\quad 5.7$ & $-43,725.8$ & - \\
\hline Toolangi & .01 & .18 & -11.0 & $-56,321.8$ & - \\
\hline Trelew & -.17 & 6.96 & -50.6 & $-18,783.4$ & - \\
\hline Vostok & .06 & -5.37 & 232.2 & $-63,269.3$ & - \\
\hline Watheroo & .02 & .58 & -40.6 & $-51,977.7$ & - \\
\hline Wilkes & .82 & -26.66 & 322.1 & $-66,350.4$ & - \\
\hline
\end{tabular}

注）時刻の原点は，1900.0年である。

た。これらのらち，明らかに符号が間違っている と考えられるものは訂正し，正しいと考えられる ものと共に採用したが，誤りかどうかがはっきり しないものは不採用とした。

年度化成に際して短周期変化を無視したこと， 収集されたデータはすべて転記されたものである こと等を考慮して，前記の吟味を終えた後なおを の差が2,000nT 以上あるものについては，採用 しなかった。これによって，自然的あるいは人為 的原因によって生ずる可能性のある大きな誤り が, データから除去されたと考えている。

\section{IX データの調整}

エポックに化成されたデータから磁気図を作成 するには，いくつかの方法がある。第 1 は, デー タに忠実に，フリーハンドでコンター線を描くも ので，狭い地域での分布を詳しく調べるのに適し ている。
第 2 は, 各成分が経緯度の 2 次式であらわされ ると仮定して，最小二乗法によってこれらの式を 決定する方法である。この方法は，日本程度の広 さの地域での分布を，世界的規模の分布の一部と して考える場合に有効である。国土地理院で作成 している国内の磁気図の場合にはこれら 2 種のコ ンターを重ねて表示してある。

南極磁気図の場合には, 観測点の数が少なくか つ地域的に偏っていること，1成分の観測しかな い点が多いこと, 地域内に地理極及び磁極を含む こと等から，これら 2 つ方法とも適切ではない ため, ポテンシャルの球関数展開式による第 3 の 方法を採用した。すなわち, 磁気ポテンシャルを 微分して得られる $\mathrm{X}, \mathrm{Y}, \mathrm{Z}$ 及びFの式を観測方 程式として,最小二乗法によりガウス係数を求め, それを用いて分布図を描くという方法である。諸 種の事情を考慮して，今回は $\mathrm{n} \leqq 12$ とた。この 場合, 未知数としてとられるガウス係数は, 総計 
168個である。

磁気ポテンシャルは本来, 地球全域に適用され る性格のものである。収集されたデータは南緯 40 度以南のものであり, 地域的に偏った分布のデー 夕を使って解を求めると正しい結果が得られない ことが多い。このような事態を避けるためには，

表 4 ガウス係数の年変化量の経年変化

\begin{tabular}{r|r|r|r}
\hline \hline 年 & $\dot{\mathrm{g}}_{1}{ }^{0}(\mathrm{nT} / \mathrm{y})$ & $\dot{\mathrm{g}}_{1}{ }^{1}(\mathrm{nT} / \mathrm{y})$ & $\dot{\mathrm{h}}_{1}{ }^{1}(\mathrm{nT} / \mathrm{y})$ \\
\hline 1957 & 14.1 & -1.3 & -3.4 \\
58 & 15.8 & -.3 & -3.3 \\
59 & 17.0 & .4 & -3.4 \\
60 & 17.6 & 3.7 & -1.9 \\
61 & 19.6 & 6.2 & -2.0 \\
62 & 20.2 & 6.1 & -2.5 \\
63 & 20.9 & 6.5 & -3.3 \\
64 & 21.9 & 7.3 & -3.6 \\
65 & 21.2 & 5.6 & -4.4 \\
66 & 23.1 & 7.2 & -4.8 \\
67 & 23.4 & 9.8 & -7.0 \\
68 & 23.8 & 10.4 & -7.3 \\
69 & 23.8 & 10.7 & -8.7 \\
70 & 24.5 & 10.7 & -11.0 \\
71 & 25.5 & 11.5 & -9.3 \\
72 & 24.4 & 12.0 & -12.0 \\
73 & 24.3 & 12.4 & -13.5 \\
74 & 21.0 & 9.1 & -17.2 \\
& & &
\end{tabular}

表 5 求められたガウス係数

\begin{tabular}{|c|c|c|c|c|c|}
\hline $\mathrm{n}$ & $\mathrm{m}$ & $\mathrm{g}_{\mathrm{n}} \mathrm{m}(\mathrm{nT})$ & $h_{n} m(n T)$ & $\dot{\mathrm{g}}_{\mathrm{n}} \mathrm{m}(\mathrm{nT} / \mathrm{y})$ & $\dot{\mathrm{h}}_{\mathrm{n}} \mathrm{m}(\mathrm{nT} / \mathrm{y})$ \\
\hline \multirow[t]{2}{*}{1} & 0 & $-30,164$ & & 24.4 & \\
\hline & 1 & $-2,026$ & 5,690 & 14.5 & -16.8 \\
\hline \multirow[t]{3}{*}{2} & 0 & $-1,920$ & & -23.2 & \\
\hline & 1 & 3,003 & $-2,016$ & 2.3 & -3.9 \\
\hline & 2 & 1,580 & -43 & 9.4 & -22.9 \\
\hline \multirow[t]{4}{*}{3} & 0 & 1,306 & & -4.2 & \\
\hline & 1 & $-2,158$ & - 397 & -13.7 & 6.9 \\
\hline & 2 & 1,269 & 254 & -9.1 & 4.7 \\
\hline & 3 & 800 & -248 & .6 & -8.0 \\
\hline \multirow[t]{5}{*}{4} & 0 & 960 & & -2.7 & \\
\hline & 1 & 818 & 169 & 2.6 & 0.0 \\
\hline & 2 & 476 & -264 & -5.5 & -0.5 \\
\hline & 3 & $\begin{array}{l}-\quad 391 \\
\end{array}$ & 28 & -5.9 & 3.7 \\
\hline & 4 & 240 & -306 & 3.2 & -1.1 \\
\hline
\end{tabular}

データの久けている地域に追加データが必要であ るが，実際問題としてこれらは入手できないの で，IGRF 1975による計算值をデータと見なして 追加した。これらの計算は, 南緯60度から北緯60 度までは経緯度各 10 度ごとの格子点, それ以外の 地域では緯度 10 度, 経度 20 度ごとの格子点, 合計 540点について行われた。

年度化成に際してポテンシャルの年変化量を用 いた理由及び11観測所を追加した理由も，これと 同様である。

このようにして求められた, エポックにおける ガウス係数を, 先に得られたその年変化量ととも に表 5 に示す。

\section{X 磁気図の作成}

求められたガウス係数及びその年変化量を用い て, 各成分及びその年変化量を格子点において計 算した。格子点の間隔は, 緯度は 1 度ごとである が，経度は緯度により異なり，次のとおりであ る。

\begin{tabular}{cc|c}
\hline \hline 緯 & 度 & 経度間 隔 \\
\hline $40^{\circ} \mathrm{S} \sim 60^{\circ} \mathrm{S}$ & $1^{\circ}$ \\
61 & $\sim 80$ & 2 \\
81 & $\sim 85$ & 6 \\
86 & $\sim 89$ & 12
\end{tabular}

これらの格子点值から， 内捙によってコンター線 の通る位置を定め，これ を次々に追跡してコンタ 一線を描いた。

作成図は, 7 種の各成 分について成分值及びそ の年変化量を 1 枚に描き 入れたもの 7 枚, 及び $\mathrm{F}$ の化成值加計算值を減 じた残差の分布図 1 枚, 合計 8 枚である。前者は 基図上に赤及び青のコン ター線で描かれており， 後者は残差を 7 段階に区 
南極磁気図の作成

表 5 つづき

\begin{tabular}{|c|c|c|c|}
\hline $\mathrm{n}$ & $\mathrm{m}$ & $\left.g_{n} m(n T)\right)$ & $h_{n}{ }^{m}(n T)$ \\
\hline \multirow[t]{6}{*}{5} & 0 & -221 & \\
\hline & 1 & 364 & 33 \\
\hline & 2 & 274 & 133 \\
\hline & 3 & -16 & -136 \\
\hline & 4 & -169 & -101 \\
\hline & 5 & $-\quad 38$ & 76 \\
\hline \multirow[t]{7}{*}{6} & 0 & 59 & \\
\hline & 1 & 55 & -23 \\
\hline & 2 & 8 & 117 \\
\hline & 3 & -218 & 78 \\
\hline & 4 & 8 & -40 \\
\hline & 5 & -10 & -13 \\
\hline & 6 & -115 & -5 \\
\hline \multirow[t]{8}{*}{7} & 0 & 75 & \\
\hline & 1 & -53 & -84 \\
\hline & 2 & 5 & -27 \\
\hline & 3 & 7 & -2 \\
\hline & 4 & $-\quad 19$ & 3 \\
\hline & 5 & -8 & 30 \\
\hline & 6 & 17 & -17 \\
\hline & 7 & -11 & -11 \\
\hline \multirow[t]{9}{*}{8} & 0 & -13 & \\
\hline & 1 & 11 & 34 \\
\hline & 2 & -9 & -30 \\
\hline & 3 & -1 & 9 \\
\hline & 4 & $-\quad 22$ & - \\
\hline & 5 & 11 & 3 \\
\hline & 6 & -14 & 20 \\
\hline & 7 & 17 & -14 \\
\hline & 8 & 0 & -20 \\
\hline \multirow[t]{8}{*}{9} & 0 & - & \\
\hline & 1 & 2 & 2 \\
\hline & 2 & 2 & 6 \\
\hline & 3 & $-\quad 3$ & -2 \\
\hline & 4 & 2 & 2 \\
\hline & 5 & 4 & -3 \\
\hline & 6 & -3 & 5 \\
\hline & 7 & 0 & 4 \\
\hline
\end{tabular}

分し，区分ごとに色分けした丸印で，同じ基図上 の観測点の位置に表示されている。従って, 後者 は観測点の分布図も兼ねているが，Zの観測しか されていない点は表示されていない。
表 5 つづき

\begin{tabular}{|c|c|c|c|c|c|}
\hline \multirow[t]{2}{*}{$\mathrm{n}$} & \multirow{2}{*}{$\frac{\mathrm{m}}{8}$} & \multicolumn{2}{|c|}{$\mathrm{g}_{\mathrm{n}} \mathrm{m}(\mathrm{n} T)$} & \multicolumn{2}{|c|}{$h_{n} m(n T)$} \\
\hline & & - & 3 & - & 1 \\
\hline & 9 & & 0 & & 0 \\
\hline \multirow[t]{11}{*}{10} & 0 & - & 1 & & \\
\hline & 1 & - & 3 & - & 3 \\
\hline & 2 & & 2 & & 2 \\
\hline & 3 & & 0 & - & 2 \\
\hline & 4 & & 2 & & 1 \\
\hline & 5 & - & 4 & - & 1 \\
\hline & 6 & & 4 & - & 2 \\
\hline & 7 & - & 2 & - & 5 \\
\hline & 8 & & 4 & & 1 \\
\hline & 9 & & 1 & & 1 \\
\hline & 10 & & 0 & & 0 \\
\hline \multirow[t]{12}{*}{11} & 0 & & 3 & & \\
\hline & 1 & & 1 & - & 5 \\
\hline & 2 & - & 1 & & 1 \\
\hline & 3 & - & 1 & & 0 \\
\hline & 4 & & 1 & - & 3 \\
\hline & 5 & - & 3 & & 2 \\
\hline & 6 & & 2 & - & 2 \\
\hline & 7 & - & 1 & & 1 \\
\hline & 8 & & 0 & & 1 \\
\hline & 9 & - & 4 & - & 4 \\
\hline & 10 & & 2 & - & 1 \\
\hline & 11 & - & 1 & & 0 \\
\hline \multirow[t]{13}{*}{12} & 0 & & 2 & & \\
\hline & 1 & & 1 & & 2 \\
\hline & 2 & & 0 & - & 4 \\
\hline & 3 & - & 1 & & 4 \\
\hline & 4 & - & 5 & & 1 \\
\hline & 5 & & 9 & & 2 \\
\hline & 6 & - & 7 & & 1 \\
\hline & 7 & & 6 & & 6 \\
\hline & 8 & - & 7 & - & 5 \\
\hline & 9 & & 8 & & 7 \\
\hline & 10 & - & 6 & & 1 \\
\hline & 11 & & 4 & & 1 \\
\hline & 12 & & 0 & - & 1 \\
\hline
\end{tabular}

基図は縮尺 1,500 万分の 1 のステレオグラフィ ック投影によるもので, 南極を中心として南緯55 度以南の地域について記載されている。 


\section{XI まとめ}

磁気図作成のための理論は周知のものであり, 作成に当って力を注いだのは，与えられた条件の 下でいかに効率的に作業を進めるかということで あった。例えば, シュミット球関数は計算中にし ばしば使われるので，あらかじめ

$$
\mathrm{P}_{\mathrm{n}}^{\mathrm{m}}(\theta)=\sin ^{\mathrm{m}} \theta \sum_{\mathrm{i}=0}^{\mathrm{n}-\mathrm{m}} \mathrm{a}_{\mathrm{nmi}} \cos ^{\mathrm{i} \theta}
$$

として $\mathrm{a}_{\mathrm{nmi}}$ を求めておき， $\theta$ が与えられれば直 ちに計算できるようにした。 $a_{n m i}$ の計算には，通 常用いられる漸化式あるいは直接計算式ではなく 新しい関係 $\mathrm{P}_{\mathrm{n}} \mathrm{m}(\cos \theta)$ を導入して漸化式

$$
\begin{aligned}
\mathrm{P}_{\mathrm{n}} \mathrm{m}(\cos \theta)= & \frac{1}{\sqrt{(\mathrm{n}+\mathrm{m})(\mathrm{n}-\mathrm{m}+1)}} \\
& \frac{\mathrm{d}}{\mathrm{d}(\cos \theta)} \mathrm{P}_{\mathrm{n}}^{\mathrm{m}-1}(\cos \theta)
\end{aligned}
$$

を用いた。この関数とシュミット球関数とは

$$
\left.\begin{array}{l}
\mathrm{P}_{\mathrm{n}}{ }^{\circ}(\theta)=\frac{1}{\sqrt{2}} \mathrm{P}_{\mathrm{n}}{ }^{\circ}(\cos \theta) \\
\mathrm{P}_{\mathrm{n}}{ }^{\mathrm{m}}(\theta)=\sin ^{\mathrm{m} \theta} \mathrm{P}_{\mathrm{n}}{ }^{\mathrm{m}}(\cos \theta) \quad \mathrm{m} \geqq 1
\end{array}\right\}
$$

という関係にある。

今回の計算では, データとして IGRF 1975に よる計算值を加宇てあることから，南極地域にお いては実際の分布と IGRF の分布との加重平均 が得られていると考えることができよう。また，

観測点の高さを無視し，高度補正を行わなかった ことから，得られた分布は棈円体面上のものとい うよりも，地表での分布に近いと考えられる。

ガウス係数から，磁極の位置及び双極子モーメ ントが求められる。

磁極は水平成分が消失する点として定義される が，今回の結果によれば，南磁極の位置は

$$
\begin{aligned}
& \mathrm{B}=65.8^{\circ} \mathrm{S} \\
& \mathrm{L}=139.3^{\circ} \mathrm{E}
\end{aligned}
$$

である。この值は，アメリカで求められたもの6) と殆んど一致している。南磁極は, 南極大陸内部 にあってアデリーランドの沿岸に向って移動して いるとされていたが，今回の結果は従来の移動方 向の延長線上にあり，完全に海上に出ていること が注目される(図 3 )。

地磁気を, 地心に置かれた棒磁石によるものと
その他のものとに分けた場合, 棒磁石の強さ（双 極子モーメント) Mは，

$$
\mathrm{M}=\left(\mathrm{a}_{0}\right){ }^{3} \sqrt{\left(\mathrm{g}_{1}\right)^{2}+\left(\mathrm{g}_{1}\right)^{2}+\left(\mathrm{h}_{1}\right)^{2}}
$$

であらわされる。今回の結果を使って計算すると，

$$
\mathrm{M}=8.0 \times 10^{25} \text { e. m. u. }
$$

となった。Mは過去100年以上にわたって減少を 続けておりて，この值もその減少傾向と一致して いる(図 4 )。

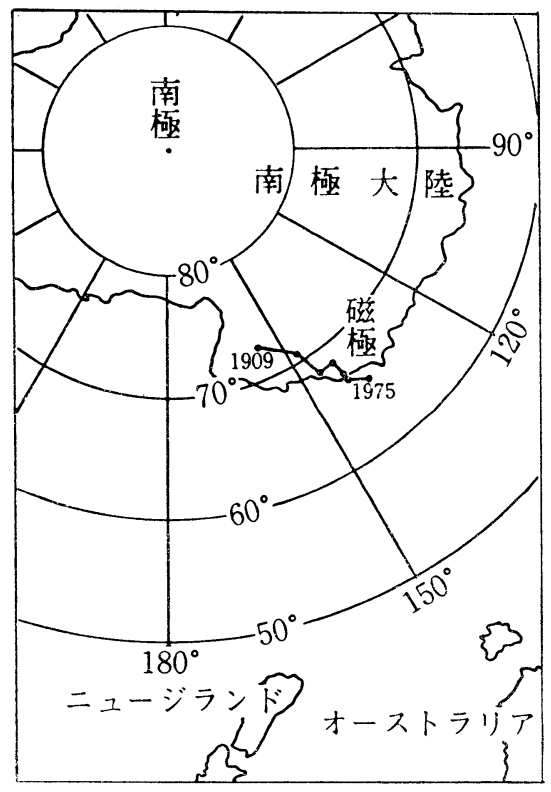

図 3 磁極の移動

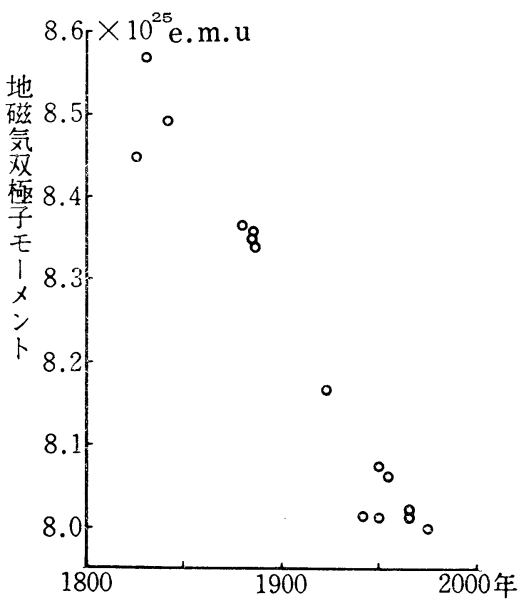

図 4 双極子モーメントの変化 (力武常次 :「地球電磁気学」による) 


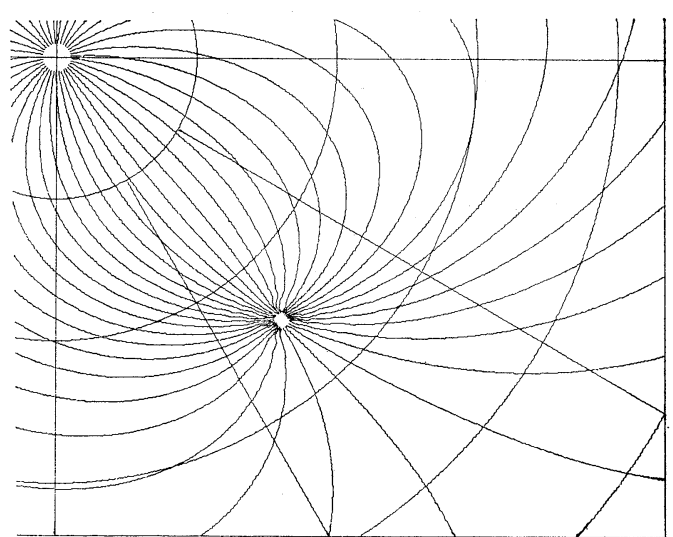

図 5 コンピュータから出力された偏角図

計算はすべて国土地理院のコンピュータ $\mathrm{NE}$ AC 2200/500を用いて行われ，コンター線及び観 测点の図上位置は X-Y プロッタにより出力され た。図 5 は, 出力された図の一部である。計算に 際して必要な定数としては, IGRF で採用されて いるものと同じ

$$
\begin{aligned}
& \mathrm{a}_{\mathrm{o}}=6371.2 \mathrm{~km} \\
& \mathrm{a}=6378.160 \mathrm{~km} \\
& \mathrm{f}=(\mathrm{a}-\mathrm{b}) / \mathrm{a}=1 / 298.25
\end{aligned}
$$

を用いた。

\section{謝 辞}

SCAR を通じて行ったデータ収集の依頼に応 ビて，下記の諸機関からデータ或いはデータに関 する情報が提供された。

Department of Natural Resources, Australia

Department of Science, Australia Institut de Physique du Globe de Paris, Universite Pierre et Marie Curie

National Institute of Polar Research, Japan

Ocean Research Institute, University of Tokyo

Department of Scientific and Industrial Research, New Zealand

Council for Scientific and Industrial Research, South Africa
Bernard price Institute of Geophysical Research, University of the Witwatersrand

British Antarctic Survey, United Kingdom Geophysical and Polar Research Center, University of Wisconsin-Madison Geological Survey, United States of America

Academy of Sciences of the USSR

これら諸機関の関係者及び終始連絡の任に当 られた SCAR 事務局長 G. E. HEMMEN 博 士，貴重な助言を与えられた SCAR 固体地球 物理ワーキンググループ幹事 C. R. BENTLEY 教授に対し，深甚の謝意を表する。 本事業を開始するにあたり，次の諸氏によっ て“南極磁気図作成ワーキンググループ”が組 織された。

小口高, 国分 征 (東京大学理学部)

行武 毅 (東京大学地震研究所)

友田好文, 小林和男 (東京大学海洋研究所) 平沢威男（国立極地研究所）

大島章一（海上保安庁水路部）

田島 稔, 藤田尚美, 春山仁（国土地理院） これらの方々にはその会合に掠いて，また個別に も種々の有益な指導助言をいただいた。極地研究 所長永田武博士，国土地理院鈴木弘道博士，同水 野浩雄氏からも指導激励をいただいた。ここに厚 く御礼を申し上げる次第である。

また，ソフトウェアの開発を分担された塚原弘 一氏並びに本事業の完遂のために労力を提供され た国土地理院地磁気係, 計算係及び地図管理部の 関係者諸氏に対し、謝意を捧げる。

\section{文献}

1) Glavnoye Upravleniye Geodezii i Kartografii MG SSSR (1966) : Atlas Antarktiki I, 34-38, Moscow.

2) Behrendt, J. C., and C. R. Bentley (1968) : Magnetic and Gravity Maps of the Antarctic, Antarcitic Map Folio Series, Folio 9, American Geographical Society, New York.

3) Chapman, S., and J. Bartels (1951): 
Geomagnetism, 2, 611-612, Oxford University Press, London.

4) IAGA Commission 2 Working Group 4 (1969) ; International geomagnetic reference field 1965.0, J. Geophys. Res., 74, 4407-4408.

5) IAGA Division I Study Group Geomagnetic Reference Fields (1976) : International geomagnetic reference field
1975, Geophys. J. R. astr. Soc., 44, 733-734.

6) Peddie, N. W., and E. B. Fabriano (1976) : A model of the Geomagnetic field for 1975, J. Geophys. Res., 81, 2539-2542.

7) 力武常次 (1972): 地球電磁気学, 87-88, 岩波書店, 東京.

（1978年 6 月 30 日受理） 